\title{
Sex Must Be Voluntary: Sexual Communication and the New Definition of Rape in Sweden
}

\author{
Linnea Wegerstad (D) \\ Senior Lecturer, Department of Law, Lund University, Sweden \\ Corresponding author: linnea.wegerstad@jur.lu.se
}

(Received 09 June 2021; accepted 17 June 2021)

\begin{abstract}
Many countries are in the process of replacing outdated sex offense regulations with laws that accurately correspond to late modern ideas about gender equality, sexual self-determination, and consensual sex. One example is Sweden, where a law that defines rape based on a criterion of nonvoluntary participation entered into force in 2018. This article analyzes the representation of rape in the new law and legal discourse in Sweden, and shows that rape is represented as a matter of choice and communication in sexual situations. Further, the new rape law is coupled to an emerging problem within such disparate spheres as public health, social media campaigns, sexual education, and gender studies; namely, the problem of sexual communication and gray zones in sexual encounters. To understand this new representation of rape, further exploration is suggested both into the effects of sexual violence being framed as a matter of individual choice, consent, and communication in late modernity and into the role of criminal law in the era of thin normativity. The article concludes that the new rape law sends a clear message about what sex should be — namely, something voluntary — but does not accurately describe the crime and the conduct that deserves criminal censure.
\end{abstract}

Keywords: Consent; voluntariness; rape reform; sexual violence; criminal responsibility

\section{A. Introduction}

Figure 1 comes from a campaign initiated by the Swedish government ${ }^{1}$ to provide information about a new rape law introduced in July 2018. ${ }^{2}$ The image's text reads: "Of [your own] free will. Sex is always voluntary; if it's not, it's a crime. So, listen, ask, and tune in so that you're sure what others really want. Because I decide about my body. Just like you decide about yours."3

I wish to thank Ulrika Andersson, Tova Bennet, and Christoffer Wong for much appreciated comments on an earlier draft of this article, and express my gratitude to the special issue editors Boris Burghardt and Leonie Steinl, whose comments have further improved the article. Financial support for writing this article came from the Swedish Crime Victim Compensation and Support Authority (Brottsoffermyndigheten) within the research project “The \#Metoo Momentum and Its Aftermath: Crime Victims' Justice-Seeking and Societal and Legal Responses".

${ }^{1}$ Governmental decision 2018-02-22 Ju2018/01290/KRIM; Kampanj för unga om frivilligt sex, https://www. brottsoffermyndigheten.se/pressmeddelande/kampanj-for-unga-om-frivilligt-sex (last visited Aug. 30, 2020). The campaign was organized by the Swedish Crime Victim Compensation and Support Authority, which also granted its permission to use the image in this article, with photo credit: Eva Edsjö.

${ }^{2}$ Proposition [Prop.] 2017/18:177 En ny sexualbrottslagstiftning byggd på frivillighet [government bill] (Swed.); Justitieutskottets betänkande 2017/18:JuU29 En ny sexualbrottslagstiftning byggd på frivillighet SFS 2018:618 (Swed.).

${ }^{3}$ Author's translation.

(C) The Author(s) 2021. Published by Cambridge University Press on behalf of the German Law Journal. This is an Open Access article, distributed under the terms of the Creative Commons Attribution licence (http://creativecommons.org/licenses/by/4.0/), which permits unrestricted re-use, distribution, and reproduction in any medium, provided the original work is properly cited. 


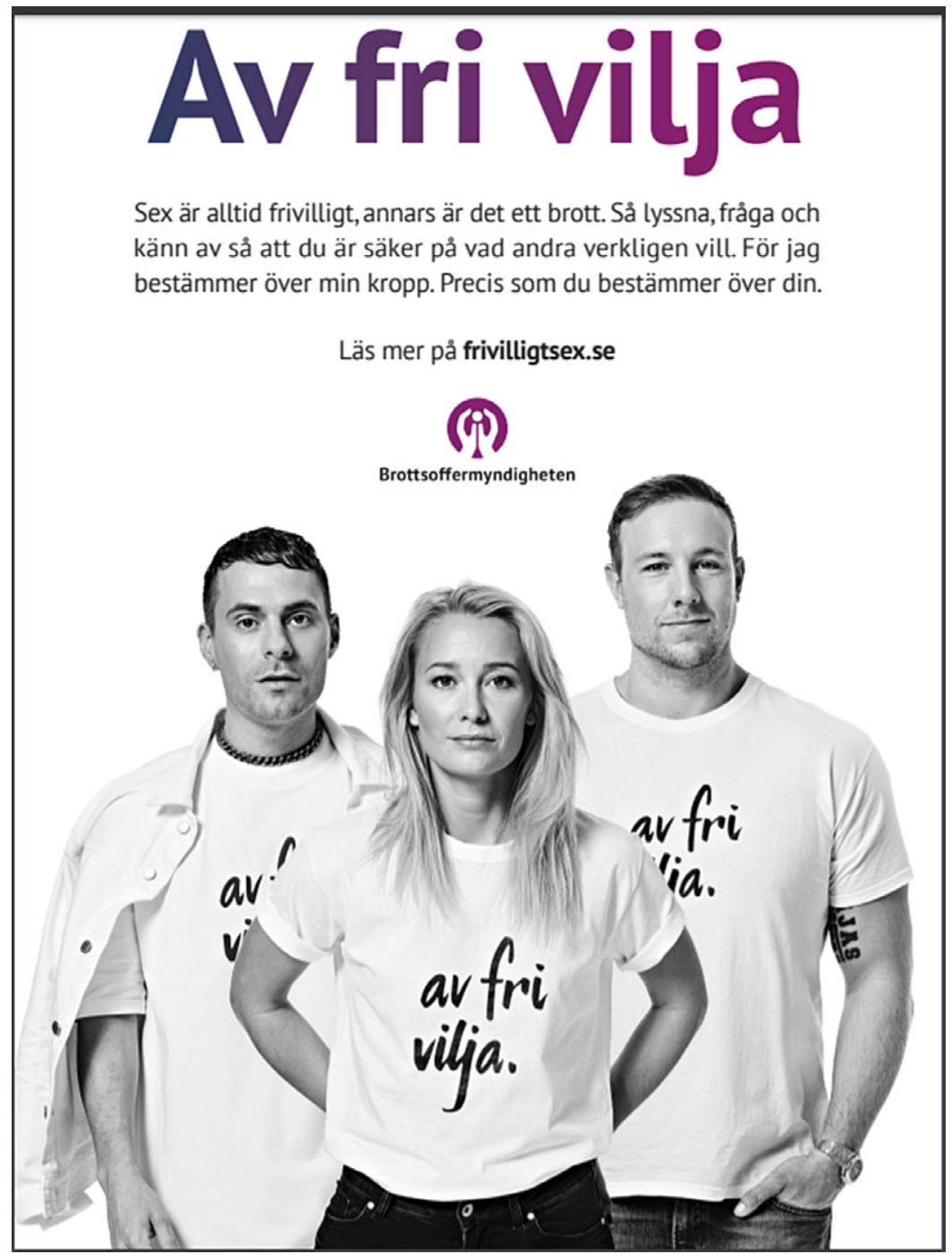

Figure 1. Campaign poster about the new rape law in Sweden. Credit: the Swedish Crime Victim Compensation and Support Authority/Eva Edsjö.

Figure 1 illustrates how the new crime of rape in Sweden-defined based on nonvoluntary participation-is framed as a matter of sex, choice, and communication. When the campaign states that "Sex is voluntary; if it's not, it's a crime," sex and crime are juxtaposed. The statement involves a description of what sex is-something voluntary, mutual, and communicative. Rape is disrespecting another person's choice: "I decide about my body" and "[y]ou decide about yours." Rape is represented as a problem of communication: The campaign assumes that individuals can express their will and encourages them to "listen, ask, and tune in." The campaign also provides advice and conveys the message that it is important for individuals to talk about sex-about what they want and feel. ${ }^{4}$ The picture exemplifies the main theme of this article, namely, that the new

${ }^{4}$ Brottsoffermyndigheten, Prata om det, https://frivilligtsex.se/prata-om-sex/ (last visited Aug. 30, 2020). 
rape law is coupled with an emerging problem within such disparate spheres as public health, social media campaigns, sexual education, and gender studies. I refer to it as the problem of sexual communication. In short, criminal law is woven into a sexual education imperative. To understand this new representation of rape, I suggest further exploration into the effects of framing sexual violence as a matter of individual choice, consent, and communication in late modernity and into the role of criminal law in the era of thin normativity. I also offer the more concrete suggestion that the application and interpretation of the new rape law should consider knowledge production within the discursive field of sexual communication.

A push to replace outdated sex offense regulations with laws that accurately correspond to late modern ideas about gender equality and sexual self-determination is taking place in many jurisdictions in Europe and North America, in addition to in international criminal law. ${ }^{5}$ The move away from force and coercion towards consent has engendered various legislative models, such as "no means no" and "only yes means yes"-also known as affirmative consent- ${ }^{6}$ and proposals to reframe rape in terms of "coercive context,"7 "consent-plus," 8 and "freedom to negotiate." In the last few years, all of the Nordic countries have had vibrant discussions on rape law reform. ${ }^{10}$ Iceland introduced a consent-based rape law in $2018 ;{ }^{11}$ Denmark adopted a new rape law similar to Sweden's in January 2021. ${ }^{12}$ Meanwhile, a legislative process in Finland is ongoing that will most probably result in a consent-based rape law, ${ }^{13}$ and Norway has heard demands for a similar move. $^{14}$

This Article looks primarily at the Swedish situation. It seeks to offer some insight into the new Swedish rape law, which is close to an affirmative consent model, as it includes no requirement that complainants express that their participation is nonvoluntary, and the main rule is that passivity on the part of the complainant should not be considered an expression of voluntary par-

\footnotetext{
${ }^{5}$ See e.g., Vanessa E. Munro, Constructing Consent: Legislating Freedom and Legitimating Constraint in the Expression of Sexual Autonomy, 41 Akron L. Rev. 923, 923-926 (2008); VAnessa E. Munro \& Clare McGlynn, Rethinking RAPE law : INTERNATIONAL AND COMPARATIVE PERSPECTIVES 1-15 (Routledge 2010); Helena Jokila \& Johanna Niemi, Rape Law and Coercive Circumstances, in RaPe IN THE Nordic Countries. Community and Change 120-21 (Marie Bruvik Heinskou, et al. eds., 2019); Janet Halley, Currents: Feminist Key Concepts and Controversies. The Move to Affirmative Consent, 42 Signs: J. Women in Culture And Soc'y 257, 261-64 (2016); Catharine A. MacKinnon, Rape Redefined, 10 Harv. L. \& Pol'y Rev. 431, 462-65 (2016); Tatjana Hörnle, The New German Law on Sexual Assault and Sexual Harassment, 18 German L.J. 1309, 1314-17 (2017); Eithne Dowds, Towards a Contextual Definition of Rape: Consent, Coercion and Constructive Force, 83 Modern L. Rev.35, 42-52 (2020).

${ }^{6}$ Tatjana Hörnle, \#MeToo - Implications for Criminal Law?, 6 BERgen J. Crim. L. \& Crim. Just., 129-30 (2019); Janet Halley, Currents: Feminist Key Concepts and Controversies. The Move to Affirmative Consent, 42 Signs: J. WOMEN IN Culture \& SOC'Y, 265 (2016).

${ }^{7}$ Catherine A. MacKinnon, Harv. L. \& Pol'y Rev. 431, 469-77 (2016).

${ }^{8}$ Vanessa E. Munro, From Consent to Coercion. Evaluating International and Domestic Frameworks for the Criminalization of Rape, in RETHINKING RAPE LAW: INTERNATIONAL AND COMPARATIVE PERSPECTIVES 22-24, (Vanessa Munro \& Clare McGlynn eds., 2010).

${ }^{9}$ Tanya Palmer, Distinguishing Sex from Sexual Violation. Consent, Negotiation and Freedom to Negotiate, in CONSENT: DOMESTIC AND COMPARATIVE PERSPECTIVES 9, 22 (Alan Reed \& Michael Bohlander eds., 2017).

${ }^{10}$ For review and critique from a human rights perspective, especially the Council of Europe Convention on Violence against Women and Domestic Violence (Istanbul Convention 2011), see generally Time for Change. Justice for Rape Survivors in the Nordic Countries, Amnesty International Report (2019), https://www.amnesty.org/en/documents/eur01/ 0089/2019/en/.

${ }^{11}$ Icelandic General Penal Code, Nr. 19/1940, Ch. XX11 Art. 194. See generally Ragnheiður Bragadóttir, Legislation on the Offence of Rape in Icelandic Criminal Law, 8 BERGEN J. CRIM. L. \& CRIM. Just. 54 (2020).

${ }^{12}$ Danish Penal Code (straffeloven), Ch. 24 Section 216; See generally Jørn Vestergaard, The Rape Law Revision in Denmark: Consent or Voluntariness as the Key Criterion?, 8 BERGEN J. CRIM. L. \& CRIM. JUST. 5 (2021).

${ }^{13}$ See generally Daniela Alaattinoğlu, et al., Rape in Finnish Criminal Law and Process - A Discussion on, and Beyond, Consent, Bergen J. Crim. L. \& Crim. Pol’y 33 (2020).

${ }^{14}$ See generally Jørn Jacobsen \& May-Len Skilbrei, Reforming the Rape Offence in Norwegian Criminal Law, 8 BERGEN J. CRIM. L. \& CRIM. JUST. 78, 87 (2020).
} 
ticipation. ${ }^{15}$ Certainly, Sweden's law must be seen in the Nordic context, with its tradition of strong welfare states, low sentences, also known as "penal exceptionalism", and explicit governmental commitment to gender equality. ${ }^{16}$ Despite this, the general conclusions drawn in this article are relevant for discussions of rape and consent, regardless of jurisdiction. My aim is neither to evaluate Sweden's chosen model for regulating rape, nor to promote alternatives to it. Instead, I aim to show how criminal rape law reform is tied up with an aspiration to sexual education in fields other than the law, and vice versa, how a criminal provision has been framed as a sexual education imperative. While there are sound reasons for decentering criminal justice in providing justice for rape victims, ${ }^{17}$ a premise of this article is that criminalization is one important measure-although it comes with certain limitationsin achieving justice and preventing sexual violence. ${ }^{18}$

My approach - analyzing how a crime is represented in the law-is methodologically inspired by Bacchi's method, "What's the problem represented to be?"19 Section B lays out the details of this approach. One explicit aim of Sweden's new rape law was to send "a clear normative message that sex without consent is illegal." ${ }^{20}$ Section C briefly describes the new law and shows that it suffers from a lack of legal certainty regarding the definition of criminal behavior. The new rape law sends a clear message about what sex should be: Namely, voluntary. The law is less straightforward when it comes to accurately describing the crime. This legal uncertainty is connected to the way that rape is represented as a matter of choice and communication in sexual situations; this is considered in Section D. Section E describes the emergent problem of sexual communication in the disparate spheres of public health, social media campaigns, sexual education, and gender studies. Connecting the dots, Section F sketches out discursive effects of the new framing of rape, while Section $\mathrm{G}$ suggests that discussions about where to draw the line for criminal responsibility may benefit from empirical knowledge about how people communicate in sexual encounters.

\section{B. What is Rape Now Represented to Be?}

A press release in March 2018 declared that the Swedish Government was proposing the introduction of a new rape law that "states the obvious", "sex must be voluntary". ${ }^{21}$ While the new law came as a timely response to the \#metoo movement's call for justice, just a few years earlier it had not been at all obvious that Sweden would or should move towards an affirmative consent model. The new rape law was the result of a process that spanned two decades and included several governmental commissions of inquiry, scholarly debate, and an intense discussion in the media of the advantages and disadvantages of a consent-based rape law. ${ }^{22}$ The reform process took place within

\footnotetext{
${ }^{15}$ Proposition [Prop.] 2017/18:177 80 En ny sexualbrottslagstiftning byggd på frivillighet [government bill] (Swed.).

${ }^{16}$ Marie Bruvik Heinskou, May-Len Skilbrei, Kari Stefansen, Rape in the Nordic Countries. Community and CHANGE 4-6 (2019).

${ }^{17}$ Linda Alcoff, Rape and Resistance: Understanding the Complexities of SeXual Violation $46-47$ (2018); Hildur Fjóla Antonsdóttir, Injustice Disrupted: Experiences of Just Spaces by Victim-Survivors of Sexual Violence, 29 SOC. \& LEGAL STUD. 718, 723-25 (2020); Clare McGlynn \& Nicole Westmarland, Kaleidoscopic Justice: Sexual Violence and VictimSurvivors' Perceptions of Justice, 28 Social \& LEGAL STUDIES 179, 180-82 (2018).

${ }^{18} \mathrm{Cf}$. Lise Gotell, Reassessing the Place of Criminal Law Reform in the Struggle Against Sexual Violence, in RAPE JUSTICE: Beyond the Criminal LaW 65-68 (Anastasia Powell, et al. eds., 2015).

${ }^{19}$ See generally Carol Lee Bacchi \& Susan Goodwin, Poststructural Policy Analysis: A Guide to Practice (2016).

${ }^{20}$ Statens Offentliga Utredningar [SOU] 2016:60 Ett starkare skydd för den sexuella integriteten, betänkande av 2014 års sexualbrottskommitté 184 [government report series] (Swed.); Proposition [Prop.] 2017/18:177 22 En ny sexualbrottslagstiftning byggd på frivillighet [government bill] (Swed.).

${ }^{21}$ Pressmeddelande från Justitiedepartementet: En ny Sexualbrottslagstiftning Byggd på Frivillighet, https://www.regeringen. se/pressmeddelanden/2018/03/en-ny-sexualbrottslagstiftning-byggd-pa-frivillighet/ (last visited Aug. 30 2020).

${ }^{22}$ Statens Offentliga Utredningar [SOU] 2001:14 Sexualbrotten, ett ökat skydd för den sexuella integriteten och angränsande frågor, betänkande av 1998 års sexualbrottskommitté [government report series] (Swed.); Statens Offentliga Utredningar [SOU] 2010:71 Sexualbrottslagstiftningen - utvärdering och reformförslag, betänkande av 2008 års sexualbrottsutredning [government report series] (Swed.). See generally Petter AsP, SEX \& SAMtycke (2010); MAdeleine
} 
a political context in which gender equality concerns increasingly led to addressing violence against women as a matter of criminal justice. ${ }^{23}$ Media coverage of several high-profile rape cases also played an important role in the debate. ${ }^{24}$ This article does not investigate the driving forces behind the reform of the law, but rather, focuses on the effects of representing rape in criminal law as a matter of sex, communication, and choice. The analysis is inspired by Bacchi's method, "[w] hat's the problem represented to be?" (hereinafter "WPR"), which involves a social constructionist approach to law and policy and aims to "open up for questioning something that appears natural and obvious." 25 This method is used in this article to investigate the seemingly now self-evident notion in crime policy - that sex must be voluntary.

While Bacchi's approach is designed to analyze problem representations in the context of policymaking processes, I will analyze a representation of a crime, treating legal texts as part of a discourse that produces a certain understanding of what rape is. ${ }^{26}$ Drawing on the work of Smart, law is considered a site of knowledge production that makes claim to truth and has the power to subjugate other discourses around, for instance, sexual violence. ${ }^{27}$ Understanding law as a discourse is useful as it "could help lawyers to recognize the limits of rational chains of arguments and to reflect on different problem formulations, arguments and interpretations." 28 My purpose is to investigate the presuppositions and assumptions present in the description of the new rape law. ${ }^{29} \mathrm{My}$ analysis consists of a close reading of the preparatory works to the reformed rape law. It focuses on the sections in each document that contain reasons for the reform, considerations regarding the exact formulation of the new law, and the descriptions - so-called explanatory notes - of how the new rape law should be interpreted and applied by legal practitioners and courts. ${ }^{30}$ In performing the text analysis, I have looked at the concepts, dichotomies, situations, and examples that are used to describe the crime. ${ }^{31}$ I pay attention to how the two main subjects in criminal legal discourse - the subject of criminal responsibility, perpetrator/defendant, and the subject of criminal protection, victim/complainant-are described. ${ }^{32}$ The analysis also considers discursive effects in the criminal justice context, by which I mean what effect representing a crime in a certain way has on allocating criminal responsibility. ${ }^{33}$ The WPR approach offers a way to understand representations of crimes in relation to problem representations in discourses outside criminal law and crime policy, for example, the problematization of sexual communication present in late modernity. In this view, the "[o]f [your own] free will" campaign

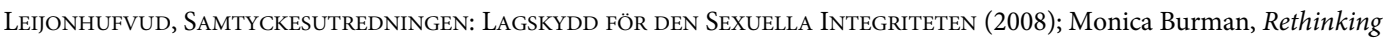
Rape Law in Sweden: Coercion, Consent or Non-Voluntariness?, in RETHINKING RAPE LAW: INTERNATIONAL AND Comparative Perspectives (Vanessa Munro \& Clare McGlynn eds., 2010).

${ }^{23}$ Monica Burman, The Ability of Criminal Law to Produce Gender Equality: Judicial Discourses in the Swedish Criminal Legal System, 16 Violence Against Women 173, 175 (2010); Katharina Tollin, Sida Vid SIDA: EN STUdie AV JÄMSTÄLLDHETSPOLITIKENS GENEALOGI 1971-2006, 133-35 (2011). For a description of the reform process, see Moa Bladini \& Wanna Svedberg Andersson, Swedish Rape Legislation from use for Force to Voluntariness - Critical Reflections from an Everyday Life Perspective, 8 BERGEN J. CRIM. L. \& CRIM. JusT. 95, 98-109 (2020).

${ }^{24}$ Gabriella Nilsson, Towards Coluntariness in Swedish Rape Law: Hyper-Medialised Group Rape Cases and the Shift in the Legal Discourse, in Rape in the Nordic Countries. Community and Change 116 (Marie Bruvik Heinskou, et al. eds., 2019).

${ }^{25}$ Bacchi \& Goodwin, Poststructural POlicy analysis 20, (2016).

${ }^{26} I d$. at 17 .

${ }^{27}$ Carol Smart, Law, Crime and Sexuality, in EsSAYs IN FEMINISM 8, 70-78 (Sage. 1995). See also Nicola Lacey, Unspeakable Subjects, Impossible Rights: Sexuality, Integrity and Criminal Law, 11 CANADIAN J.L. \& JURIS., 51 (1998).

${ }^{28}$ Johanna Niemi, Law and Crisis: Reflections on how legal problems are constructed and how they can be studied, RETFAERD, 76, 78 (2018).

${ }^{29}$ Bacchi \& GoOdWin, Poststructural POlicy anAlysis 20 (2016).

${ }^{30}$ Staten Offentliga Utredningar [SOU] 2016:60 ch. 5 \& 10 [government report series] (Swed.); Proposition [Prop.] 2017/ 18:177 ch 4-6, 13 En ny sexualbrottslagstiftning byggd på frivillighet [government bill] (Swed.).

${ }^{31}$ BACCHI, supra note 29 , at 21 .

${ }^{32}$ Ulrika Andersson, Hans (ORd) Eller Hennes?: En KÖnsteoretisk Analys av Straffrättsligt Skydd Mot SEXUELLA ÖVERGREPP 38-44 (2004).

${ }^{33}$ BACCHI, supra note 29 , at 23 . Bacchi describes effects in terms of discursive, subjectification, and lived effects. 
mentioned above not only offers information about the new rape law, but also represents rape itself in a certain way.

\section{Legal Uncertainty in the New Rape Law}

Until 2018, rape as legally defined in Sweden had to involve either coercion by assault, other violence or threat, or improper exploitation based on the fact that the complainant was in a particularly vulnerable situation due to, for example: Unconsciousness, sleep, grave fear, the influence of alcohol or drugs, illness, bodily injury, or mental disturbance. ${ }^{34}$ The question of the complainant's consent did, however, play a decisive role without being explicitly part of the old definition, and was used in court practice both in the form of a consent defense by defendants and as a hypothesis of consent applied by the court. ${ }^{35}$ One might therefore imagine that the effect of the shift from the coercion model to the consent model would be small. On the contrary, a review by the Swedish National Council for Crime Prevention (Brottsförebygganderådet, abbreviated Brå) of court cases after the 2018 reform found that 76 prosecutions for rape, of a total of 362, involved instances that would not have amounted to rape under the old law. ${ }^{36}$

Under the new law, there are three requisite elements for the crime of rape that the prosecution must prove. ${ }^{37}$ The first is that the defendant had sexual intercourse or performed some other sexual $\mathrm{act}^{38}$ that in view of the seriousness of the violation is comparable to sexual intercourse. Sexual intercourse is restricted to penile penetration of the vagina. Comparable sexual acts are genderneutral and include, for example, insertion of the penis into the anus or mouth, or penetration of the vagina or anus with objects or body parts other than the penis. The rape definition also includes situations when the complainant performs sexual acts on themselves or with a third person. The less serious crime of sexual assault exists for sexual acts that are not comparable to sexual intercourse. ${ }^{39}$

Second, to prove criminal responsibility for rape, the prosecution must prove that the person with whom the sexual act was performed did not participate voluntarily. The law specifies situations when participation may never be considered voluntary: (1) if participation is a result of an assault, other violence or a threat of a criminal act, a threat to bring a prosecution against or report another person for an offense, or a threat to give detrimental information about another person; (2) if the perpetrator improperly exploits the fact that the other person is in a particularly vulnerable situation due to unconsciousness, sleep, grave fear, the influence of alcohol or drugs, illness, bodily injury, mental disturbance or otherwise in view of the circumstances; or (3) if the perpetrator induces the other person to participate by seriously abusing their position of dependence on the perpetrator. ${ }^{40}$ If none of the above apply, but

\footnotetext{
${ }^{34}$ For the wording of the provision in force at the time, see Criminal Code Ch. 6, $₫ 1$ (SFS 2013:365) (Swed.).

${ }^{35}$ Ulrika Andersson, The Unbounded Body of the Law of Rape: The Intrusive Criterion of Non-Consent, in RESPONSIBLE Selves: Women IN THe Nordic Legal Culture 337 (Kevät Nousiainen, et al. eds., 2001).

${ }^{36}$ Brå report 2020:6 Den nya samtyckeslagen i praktiken 29 [Swedish National Council for Crime Prevention Report] (Swed.). The review included all district court judgements from 2019 that involved rape perpetrated against a woman.

${ }^{37}$ Ch. $6 \$ 1$ (Svensk författningssamling [SFS] 2018:618). The Swedish Criminal Code translated by the Swedish Governmental Office, https://www.government.se/government-policy/judicial-system/the-swedish-criminal-code/. The rape provision is applicable to adults only, i.e. when the complainant is fifteen or older-in certain circumstances eighteen or older. See Criminal Code Ch. 6, $\$ 4-6$, (SFS 2013:365) (Swed.).

${ }^{38} I d$. The term "sexual act" is not statutorily defined, but according to preparatory works, the starting point must be lasting contact between the perpetrator's body and the other person's genitals or the other person's body and the perpetrator's genitals. Acts that do not involve such lasting physical contact may, however, also be covered. In such cases, the requirements are the act had a sexual character and violated the victim's sexual integrity.

${ }^{39} \mathrm{Ch} .6, \$ 2$ Svensk författningssamling [SFS] 2018:618 (Swed.). E.g. the act of touching the genitals, without penetration, of a person not participating voluntarily, see NJA 2008 s. 482 II.

${ }^{40}$ Ch. $6 \$ 2$ (SFS 2018:618) (Swed.).
} 
participation still was not voluntary, the defendant may be found guilty under the first sentence of the relevant section of law. ${ }^{41}$

\section{Nonvoluntary Participation}

The precise meaning of nonvoluntary participation was a disputed issue in the legislative process. An official commission of inquiry proposed in 2016 that in order for participation to be considered voluntary, the choice to participate had to be expressed, and only a verbal "yes" or active participation could be interpreted as voluntary participation. ${ }^{42}$ This position drew criticism from several legal bodies to whom the proposal was referred for consideration. ${ }^{43}$ As a result, the draft bill submitted to the Council on Legislation (Lagrådet) excluded the statement that "the choice to participate must be expressed for participation to be considered voluntary" from the legal definition. ${ }^{44}$ The Council on Legislation found that the boundary between a criminal act-nonvoluntary participation — and a lawful act — voluntary participation-was mainly to be determined by the circumstances in the individual case and would be dependent upon individual judges' normative conceptions regarding what kinds of participation in sexual acts should not be deemed voluntary. ${ }^{45}$ The Council therefore found it not possible to predict in which cases the conditions for criminal responsibility would be fulfilled, and so advised against implementation based on the principle of legality. In response to this criticism, the bill eventually accepted by Parliament instead includes the following sentence; "[w]hen assessing whether participation is voluntary or not, particular consideration is given to whether voluntariness was expressed by word or deed or in some other way." 46 The purpose of this sentence was to more clearly demarcate the area of criminalized behavior.

The new rape law may be better understood if considered in the light of the different scenarios of communication described by Hörnle. ${ }^{47}$ A scenario where the complainant communicated that they did not want to participate in a sexual act_- no means no"-is clearly considered to be rape, as communicating a no-verbally or by other means - is a sufficient requirement for criminal responsibility. "Only yes means yes," or affirmative consent, describes a scenario where the complainant could have communicated that their participation was nonvoluntary but did not do soand where none of the situations in points one through three enumerated above exist. The Swedish law does not state that a defendant can be held liable for rape solely on the ground that the other person did not say yes. Yet there is no requirement for the complainant to have expressed that their participation was nonvoluntary; a person can still be held liable for rape even when any outward expression of nonvoluntary participation is absent. According to the Bill, the assumption is that persons who participate voluntarily in a sexual act will express their desire to do so, and that the lack of such expression should normally be interpreted as nonvoluntary participation. ${ }^{48}$ The explanatory notes state that in exceptional cases, tacit consent to sexual interaction may be enough to ground voluntariness, but if the complainant denies voluntary participation, it should be required that something exists to suggest consent - for the defendant to avoid conviction. ${ }^{49}$ The Supreme Court of Sweden has stated, in the one rape case it has heard so far concerning the new rape law, that there is "limited room for assessing pure passivity as an expression of a

\footnotetext{
${ }^{41}$ Proposition [Prop.] 2017/18:177 37-38 [government bill] (Swed.).

${ }^{42}$ Statens Offentliga Utredningar [SOU] 2016:60 73 [government report series](Swed.).

${ }^{43}$ Proposition [Prop.] 2017/18:177 31-33 [government bill] (Swed.).

${ }^{44}$ Draft bill to the Council on Legislation Dec. 21, 2017.

${ }^{45}$ The Council's statement of opinion, appendix 8, Proposition [Prop.] 2017/18:177 132 [government bill] (Swed.).

${ }^{46} \mathrm{Ch} .6 \$ 1$ (Svensk författningssamling [SFS] 2018:618) (Swed.).

${ }^{47}$ Hörnle, supra note 6, at 129-31.

${ }^{48}$ Proposition [Prop.] 2017/18:177 80 [government bill] (Swed.).

${ }^{49} I d$.
} 
choice to participate in a sexual act." 50 The Swedish model may most accurately be described as a modified affirmative consent model: "[O]nly yes means yes-with some exceptions."

I would contend that the new rape law suffers from a lack of predictability. There is no legal definition of nonvoluntary participation and it is left to the courts to decide in each individual case whether voluntary participation is present. ${ }^{51}$ The explanatory notes in the Bill provide general guidelines for the interpretation and application of the new law. ${ }^{52}$ For instance, the notes say that a person who agrees to participate after prolonged persuasion is participating voluntarily, whereas voluntary participation normally does not exist in situations where a person is unexpectedly assaulted via a sexual act - for example, during a medical examination or in public gatherings. ${ }^{53}$ Despite these guidelines, it is not obvious what behavior, situations, or signs should constitute legally valid expressions of voluntary or nonvoluntary participation. Further, there is room for uncertainty regarding when passivity on the part of the complainant should be interpreted as tacit consent, and when it is a sign of nonvoluntary participation. The supposedly clear message that sex should be voluntary is not so clear-cut when it comes to defining-before a case ends up in court-what rape is. ${ }^{54}$ The explanatory notes use language like "normally" and "exceptional situations" and say that something "may" be a crime, indicating broad scope for discretion. This uncertainty has had consequences for court practice, as the Brå review cited above shows. In one third of new cases that led to an acquittal, the acquittal was owing to the fact that the complainant's signs of nonvoluntary participation were considered to be too vague. ${ }^{55}$ The same review also shows that case outcome may depend upon individual judges' subjective perception of what kind of behavior constitutes an expression of sexual interest. ${ }^{56}$ Further, there are difficulties in assessing whether participation was nonvoluntary in cases where clear signs of unwillingness are mixed with more ambivalent expressions that could be interpreted as expressions of voluntariness. ${ }^{57}$ According to the Brå review, more clarity is needed on the kinds of circumstances where signs of voluntary participation should be deemed invalid, thus potentially leading to a rape conviction. ${ }^{58}$

\section{Intent and Negligence}

Third, to prove criminal responsibility, the prosecution must prove that the defendant acted with criminal intent. ${ }^{59}$ Regarding rape cases and the question of voluntary participation, the intent requirement is fulfilled if the defendant was certain that the complainant's participation was nonvoluntary. This means that the defendant knew of the circumstances that are required for criminal responsibility for rape-for example — that the complainant did not participate voluntarily, was heavily intoxicated, or participated in the sexual act due to violence. The intent requirement is also

\footnotetext{
${ }^{50}$ Nytt Juridiskt Arkiv [NJA] [Supreme Court Reports] 2019_s. 668 p. 15 (Swed.).

${ }^{51}$ Proposition [Prop.] 2017/18:177 33 [government bill] (Swed.).

${ }^{52} I d$ at 78-79. The explanatory notes are not binding but often referred to in court cases. According to the explanatory notes, the assessment of voluntary participation should be based on the situation as a whole. Voluntariness must be present when the sexual act is performed, and an indication in advance that one wants to participate does not imply that later participation in a sexual act is voluntary. Further, participation can be voluntary for a person even if that a person does not have full insight into relevant conditions: to deceive someone into having sex through false statements concerning, for example, celebrity status, age, occupation, transgender identity, or contraceptive use does not make participation nonvoluntary. It is noted that in some cases, making such misleading statements might amount to the exploitation of a vulnerable situation.

${ }^{53} I d$.

${ }^{54}$ Suzanne Wennberg, Befogad Kritik av det nya Våldtäktsbrottet?, JURIDISK TIDSKRIFT 298, 301 (2018).

${ }^{55}$ Brå report 2020:6 43.

${ }^{56} I d$. at 45 .

${ }^{57} I d$. at 48 .

${ }^{58}$ Id. at 50 .

${ }^{59}$ Ch. $1 \S 2$ (Svensk författningssamling [SFS] 1994:458)(Swed.); Suzanne Wennberg, Criminal Law, in SwEDISH LEGAL SYSTEM 164-65, (Michael Bogdan ed. 2010).
} 
fulfilled if the defendant has shown so-called "indifference intent" (likgiltighetsuppsåt). Indifference intent, in brief, means that the defendant appreciated that there was a risk that the complainant was not participating voluntarily - a cognitive status - and was indifferent to whether or not that was true-a volitional status. The updated rape law also introduced the new crime of negligent rape. Negligent rape covers situations where the defendant did not have criminal intent but showed gross negligence in relation to the circumstance that the other person was not participating voluntarily. ${ }^{60}$ Gross negligence includes situations where the defendant appreciated there was a risk - suspected — that the complainant was not participating voluntarily, but nevertheless went through with the sexual act. ${ }^{61}$ Gross negligence also, however, includes situations where the defendant did not actually appreciate such a risk, but should and could have done so. To be held criminally liable for negligent rape in these situations requires that what the defendant could do is something that he or she also ought to do. Further, the defendant's negligence must be "clearly reprehensible" (klart klandervärd) ${ }^{62}$

Uncertainties exist regarding the mental element. Concerning indifferent intent, there is room for discretion in judging whether the defendant realized the risk that the complainant did not participate voluntarily. ${ }^{63}$ According to the explanatory notes cited above, only negligence that is "clearly reprehensible" should be punished, which leaves considerable scope for interpretation regarding what is blameworthy behavior in sexual situations. The Brå review of court cases shows that written judgments use a variety of formulations to describe the defendant's understanding, and that difficulties arise when seeking to determine whether the defendant has shown indifference. ${ }^{64}$

The point of this brief account of the new rape law in Sweden is not to evaluate it as either a failure or a success. The number of rape prosecutions increased after the reform by more than the increase in reported rapes. ${ }^{65}$ This indicates, according to the Bra review, that the new rape law facilitated the prosecution of reported cases in the criminal justice system. ${ }^{66}$ In addition, the number of rape convictions has risen significantly-from 190 convictions in year 2017 to 333 convictions in $2019 .{ }^{67}$ According to the review, the most probable explanation for this rise is that the aim of the new law has been fulfilled: Sexual violence that could not be successfully prosecuted under the old law now can be. ${ }^{68}$ My point is to underscore that both at the level of actus reus-whether participation was nonvoluntary-and at the level of mens rea-what the defendant knew or should have known about whether the participation of the other person was voluntary-the law leaves considerable room for interpretation. One might object that court discretion is common in criminal law, and not a problem specific to rape cases. Further, some uncertainty may be resolved with the help of future clarifications from the Supreme Court. I suggest, however, that the problem is also of a different kind. Insofar as the law now represents the crime of rape as a matter of choice and communication in sexual situations, attribution of criminal responsibility necessarily relates to normative assumptions about how people behave and should behave in sexual encounters. This is not entirely new. Rape trials have a history of being saturated with normative and gendered assumptions about female sexuality in particular-and this is regardless of

\footnotetext{
${ }^{60} \mathrm{Ch} .6 \$ 1$ (Svensk författningssamling [SFS] 2018:618)(Swed.).

${ }^{61}$ Proposition [Prop.] 2017/18:177 85 [government bill] (Swed.).

${ }^{62} I d$.

${ }^{63}$ Nytt Juridiskt Arkiv [NJA] [Supreme Court Reports] 2019_s. 668 p. 24-26 (Swed.). The risk must be considerable from the point of view of the defendant. In rape cases, the Supreme Court has stated, only very limited guidance can be drawn from the actual risk. Further, the defendant's age, maturity, and mental health can have significance in this assessment.

${ }^{64}$ Brå report 2020:6 53.

${ }^{65} I d$. at 24 . From 236 suspects in 2017 to 425 suspects in 2019.

${ }^{66} I d$. at 25 .

${ }^{67} I d$. at 26 .

${ }^{68} I d$. at 28 .
} 
whether the rape laws are based on coercion or consent. ${ }^{69}$ What is new is that the updated definition of rape explicitly refers to normative behavior in sexual situations and implies an educational imperative-sex must be voluntary. Therefore, the uncertainties I have mentioned are better understood if they are not treated solely as a matter of accuracy in a narrow legal sense; I do not consider a more stringent wording of the rape provision the key. Instead, these uncertainties are better considered as part of a broader context in which rape is framed as a problem of sexual communication. The next section describes in more detail how rape is represented in criminal law discourse as a matter of choice and communication in sexual situations.

\section{Rape as a Matter of Choice and Communication in Sexual Situations}

This section shows that the updated law on rape in Sweden now represents rape as a matter concerning choice and communication between gender-neutral subjects in sexual situations. The subject of criminal protection - the claimant-is expected to make a choice, and this choice is the determining factor for whether a crime has been committed. This characterization of rape tells us what subjects should do to avoid having nonvoluntary sex, but is less explicit regarding the requirements for criminal responsibility.

From the outset, the new legislation positions rape in the context of positive sexuality, where sexuality is described as a natural and pleasurable part of human life. ${ }^{70}$ It draws a boundary between sex on the one hand - which is voluntary, thus positive, good, and valuable - and crime on the other-nonvoluntary, thus negative, bad, and punishable. With crime and sex juxtaposed in this fashion, the way that rape is presented relies on describing what is not a crime. The sexuality on which the law is based is one of equality and mutuality. For example, one point of emphasis is that the concepts used in the legal definition of rape should not reflect inequality in sexual relations,

"Concepts such as allowance and permission are, in our opinion, not entirely successful, as they can to some extent be considered to express an inequality between the parties who participate in sexual relations. What should instead be the starting point is that sexual relations are basically something positive and grounded in reciprocity."71

The updated law also sets rape in relation to an understanding of how people behave and communicate when they have sex. For example, the preparatory works state that sexual relations are seldom preceded by a detailed discussion between the parties about what should happen, and that the sexual act develops gradually through the partners' actions, for example, through the mutual exchange of kisses, hugs, and caresses. ${ }^{72}$ Just as rape is defined in relation to a conception of what sex is, it also rests on a normative comprehension of what sex should be-namely, mutual and voluntary. ${ }^{73}$ This normative idea of sex is also, as described above, something the legislative reform explicitly aimed to achieve. ${ }^{74}$ Explanations of how to interpret the new definition contain implicit

\footnotetext{
${ }^{69}$ See generally Carol Smart, Feminism and the Power of LAW 26-49 (Routledge. 1989); Naffine Ngaire, Possession: Erotic Love in the Law of Rape, 57 The Modern L. Rev. 10 (1994); Stevi Jackson, The Social Context of Rape: Sexual Scripts and Motivation, 1 Women's Stud. Int'L Q. 27 (1978); Andersson, Hans (Ord) Eller Hennes? 2004; Simon

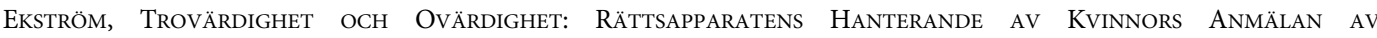
VÅLDTÄKTSBROTT STOCKHOLM 1946-50 (2002).

${ }^{70}$ Statens Offentliga Utredningar [SOU] 2016:60 176 [government report series](Swed.); Proposition [Prop.] 2017/18:177 21 [government bill] (Swed.).

${ }^{71}$ Author's translation of Statens Offentliga Utredningar [SOU] 2016:60 194-95 [government report series](Swed.).

${ }^{72}$ Id. at 198.

${ }^{73}$ Id. at 184; Proposition [Prop.] 2017/18:177 22 [government bill] (Swed.).

${ }^{74}$ Statens Offentliga Utredningar [SOU] 2016:60 184 [government report series] (Swed.); Proposition [Prop.] 2017/18:177 22 [government bill] (Swed.).
} 
suggestions of how people should behave in sexual situations. For example, "[i]f any participant changes their behavior from being active to becoming passive, there is often reason for other participants to check with them that participation is still voluntary, e.g. by asking an explicit question." 75 This passage also exemplifies the way that rape is represented as something that happens in a situation that is already sexual. The Swedish word for "participate," "delta," which is used in the criminal definition, means to participate with other people in a collective activity. ${ }^{76}$ Rape is represented as miscommunication in a joint venture that from the outset is sexual. ${ }^{77}$ An exception is rape represented as an unexpected assault in a situation that is not sexual, for example, during a medical examination or during a crowded concert. ${ }^{78}$ To sum up, the law represents rape as something juxtaposed with sex-if the act is not voluntary, it is rape; if it is voluntary, it is sex. The representation of the crime is dependent upon descriptions of sexual acts, situations, and behaviors that are voluntary, and upon subjects involved in a joint sexual activity. The subjects are not gendered, with only a few exceptions. ${ }^{79}$

The focal point for attributing criminal responsibility, moreover, is choice. To be more precise, it is the choice made by the subject of criminal protection that matters. The preparatory works state that the primary good to be protected in sexual offenses is sexual self-determination, along with sexual integrity. ${ }^{80}$ But another aspect of choice is that its presence is a precondition for consent. Representing rape as a matter of sex/not sex implies that the subject of criminal protection must make a decision - to participate or not to participate. ${ }^{81}$ Choice as the key determinant for criminal responsibility builds upon three distinctions.

First, choice is something other than the subject's inner will, and the subject's inner will is not decisive for criminal responsibility. ${ }^{82}$ This is motivated by the right to self-determination-one has the right to choose to have sex that one might not want-and the notion that a person who has sex with someone who has expressed that he or she wants to participate should be able to rely on that. ${ }^{83}$ The subject of criminal protection can want one thing but choose the other. This distinction has been described as consensual sex as opposed to wanted sex, ${ }^{84}$ or as positive consent as opposed to constrained consent. ${ }^{85}$

Second, there is the distinction between on the one hand the subject's choice and on the other hand expressions of that choice, also known as performative consent. ${ }^{86}$ As mentioned above, opinions diverged regarding the governmental commission's proposal that if the complainant did not express their choice to participate voluntarily in a sexual act, that should be sufficient to ground

\footnotetext{
${ }^{75}$ Statens Offentliga Utredningar [SOU] 2016:60 428-429 [government report series](Swed.).

${ }^{76}$ Svenska Akademiens Ordbocker, Svensk Ordbok Utgiven av Svenska Akademien, www.svenska.se/ (last visited Aug. 27 2020).

${ }^{77}$ Svensk Offentliga Utredningar [SOU] 2016:60 428-429 [government report series] (Swed.); Proposition [Prop.] 2017/ 18:177 31 [government bill] (Swed.).

${ }^{78}$ Proposition [Prop.] 2017/18:177 35 [government bill] (Swed.).

${ }^{79}$ Svensk Offentliga Utredningar [SOU] 2016:60 205, 219, 246, 431 [government report series] (Swed.); Proposition [Prop.] 2017/18:177 80 [government bill] (Swed.).

${ }^{80}$ Svensk Offentliga Utredningar [SOU] 2016:60 176-77 [government report series] (Swed.); Proposition [Prop.] 2017/ 18:177 15 [government bill] (Swed.). There is no clear distinction between sexual self-determination and sexual integrity in the preparatory works, and they are often used together to describe the primary good in sexual offense cases, as in the statement that the point of departure for the legislation is that every person in every situation has the right to decide about his or her own body and sexuality and that his or her desire not to engage sexually must be unconditionally respected. See Proposition [Prop.] 2004/05:45 En ny Sexualbrottslagstiftning 21-22 [government bill] (Swed.).

${ }^{81}$ Svensk Offentliga Utredningar [SOU] 2016:60 196-197 [government report series] (Swed.); Proposition [Prop.] 2017/ 18:177 33, 78 [government bill] (Swed.).

${ }^{82}$ Proposition [Prop.] 2017/18:177 33 [government bill] (Swed.).

${ }^{83}$ Svensk Offentliga Utredningar [SOU] 2016:60 198 [government report series] (Swed.); Proposition [Prop.] 2017/18:177 33 [government bill] (Swed.).

${ }^{84}$ Robin L. West, Consensual Sexual Dysphoria: A Challenge for Campus Life, 66 J. LEGAL EduC. 804, 806 (2017);

${ }^{85}$ Halley, supra note 6 at 265 (2016).

${ }^{86} I d$.
} 
criminal responsibility for rape. Both positions have in common that they see the new rape law as addressing the problem of what the subject of criminal protection wants, chooses, and expresses. When the documents discuss situations where there is ambivalence regarding whether they should fall under the new definition of rape, those discussions are concerned with a lack of congruity on the part of the subject of criminal protection-when the subject wants one thing, but chooses the other, or expresses neither what they want nor what they choose. One such borderline situation where inner will differs from choice is so-called "tjatsex", a word used in the Bill whose literal translation is "nag-sex" meaning when a person after much persuasion makes the choice to participate in a sexual act. ${ }^{87}$ Further, the complainant's passivity appears as a problem when defining rape, indicating an underlying assumption that choice is normally expressed in some way in sexual situations. The right to express choice through passivity, however, is also held to exist,

"A person who is subjected to a sexual act against their will has no responsibility to say no or clearly show their aversion to a sexual act. Also, they have no responsibility to clearly show their desire for sexual intercourse. In the same way that everyone must decide whether he or she wants sexual intercourse, it is part of the sexual right to self-determination to respond to sexual approaches as one wishes to do, including with passivity." 88

This passage further indicates that passivity cannot be the absence of choice. It is understood as an expression either of voluntary or of nonvoluntary participation. The passive subject is constructed as a problem because passivity deviates from the presupposition that the subject knows what he or she wants, makes a choice, and expresses that choice.

A third distinction concerns situations where the ability to make a choice is restricted in such a way that criminal responsibility should be attributed. Whereas the old law defined rape in terms of the means used by the subject of criminal responsibility-force, violence, threat, exploitationthese means are still present in the new rape definition, but now as circumstances that restrict the free will of the subject of criminal protection. ${ }^{89}$ Violence and force become intelligible through the lens of voluntary participation, and it is not the violence per se that constitutes rape. For example, concerning acts of violence that do not constitute rape,

"If those who participate in sexual intercourse agree that violence should be included as part of the intercourse, the choice to participate cannot be considered a consequence of the violence. This may be the case e.g. within the framework of so-called BDSM sex." 90

In the context of intimate partner violence, too, rape is represented as a matter of the free will of the subject of criminal protection,

"It could be questioned whether persons living under a constant threat of violence in a relationship can be considered to express their free will. At the same time, there may be periods in the relationship without elements of violence or threats. The starting point must, in the Government's opinion, be that there may be voluntary sexual intercourse even in such relationships." 91

\footnotetext{
${ }^{87}$ Proposition [Prop.] 2017/18:177 33 [government bill] (Swed.).

${ }^{88} I d$. at $32-33$.

${ }^{89}$ Svensk Offentliga Utredningar [SOU] 2016:60 209, 211 [government report series] (Swed.); Proposition [Prop.] 2017/ 18:177 38 [government bill] (Swed.).

${ }^{90}$ See Proposition [Prop.] 2017/18:177 38 [government bill] (Swed.); See also Svensk Offentliga Utredningar [SOU] 2016:60 204 [government report series] (Swed.).

${ }^{91}$ See Proposition [Prop.] 2017/18:177 39 [government bill] (Swed.); See also Svensk Offentliga Utredningar [SOU] 2016:60 203 [government report series] (Swed.).
} 
Further examples of how the ability to choose is now the foundation for the distinction between sex and crime include the discussions about whether making an offer in exchange for sex limits the subject's ability to choose freely, and the discussions about situations of deception. ${ }^{92}$

Last, while the updated rape law presumes a subject of criminal protection who expresses his or her choice to engage in a sexual act, it also implies a subject of criminal responsibility who understands what the other person wants and expresses. If the choice of the subject of criminal protection is one key determinant of responsibility, the other key determinant is the ability to comprehend and interpret what the other person wants. The new law, I contend, represents rape as a matter of-failed-communication. The subject of criminal responsibility is expected to explain what made them believe that the other person participated voluntarily. ${ }^{93}$ This subject is also expected to ask questions when in doubt. ${ }^{94}$ Mutual, good, voluntary sexuality requires communication. The ability to communicate is mostly visible in the sections that describe the new crime of negligent rape, which prescribes diligence in sexual situations: "A law based on voluntary participation is founded on the premise that anyone who intends to have sexual intercourse with someone else must ensure that the will to have such intercourse is mutual. Therein lies a requirement for caution." 95

While largely invisible in sections describing in more detail what amounts to nonvoluntary participation, the subject of criminal responsibility appears the more clearly in sections on intent and negligence. The subject of criminal responsibility is expected to have communication skills and to be diligent enough to understand the other person's signals and to ask if uncertain.

To conclude, I have shown that Sweden's new law on rape represents rape as a matter concerning choice and communication between gender-neutral subjects in sexual situations. The subject of criminal protection is expected to make a choice, and this choice is the determining factor for whether a crime has been committed. I suggest that the legal uncertainty pointed out in the previous section may be related to this form of representation. By centering the crime around choice and expression on the part of the subject of criminal protection, the question of when a person is to be held responsible for rape-the distribution of punitive censure-is pushed aside. Characterizing rape in this way tells us what the subject of criminal protection should do to avoid having nonvoluntary sex, but is less explicit regarding what is required for criminal blameworthiness, apart from the fact that the subject of criminal responsibility is expected to have communicative skills and be diligent in sexual situations. Considered in a larger context, I suggest in the following sections that the way rape is represented in the new law relates to the emergent problem of sexual communication that can be found in discourses in society beyond the legal, and that it has a historical background in the shift from a thick to a thin normativity that permeates law and intimate relations in late modernity.

\section{E. The Emergent Problem of Sexual Communication}

The current representation of rape in Swedish criminal law discourse relates to an emergent problem of sexual communication described in such disparate spheres as public health, social media campaigns, sexual education, and gender studies research. This problem is characterized by a concern with gray zones in sexual encounters; behavior that does not amount to a crime, nor is good sex, but lands somewhere in between. It captures experiences of sex in these gray zones, previously

\footnotetext{
${ }^{92}$ Svensk Offentliga Utredningar [SOU] 2016:60 208, 217-218 [government report series] (Swed.).

${ }^{93} I d$. at 183; Proposition [Prop.] 2017/18:177 22 [government bill] (Swed.).

${ }^{94}$ Svensk Offentliga Utredningar [SOU] 2016:60 197 [government report series] (Swed.); Proposition [Prop.] 2017/18:177 85 [government bill] (Swed.).

${ }^{95}$ See Proposition [Prop.] 2017/18:177 23 [government bill] (Swed.); See also Svensk Offentliga Utredningar [SOU] 2016:60 270 [government report series] (Swed.).
} 
"unheard within dominant discourses on both sex and sexual violence." 96 The 2010 Twitter-initiated \#talkaboutit campaign, started by Swedish journalist Johanna Koljonen, is one example of the discourse on gray areas in sexual encounters. ${ }^{97}$ The campaign related to rape in a legal sense, as it was initiated in response to the rape accusations against Julian Assange, but the gray zones were mainly framed as a matter of sexuality rather than criminal violence. ${ }^{98}$ According to Karlsson, the hashtag campaign attempted to find a more capacious language around negative sexual situations and "sought to find discursive room for ambiguous sexual experiences in between choice and coercion." 99 The narratives of the campaign partially concerned how to express oneself when subjected to unwanted sexual advances. ${ }^{100}$

The problem of sexual communication is also, I suggest, characterized by an interest in investigating how people do communicate what they want, how they comprehend what other people want in sexual situations, and how such communication can be improved. A recent study conducted by the Swedish Public Health Agency entitled "Sexual Communication, Consent and Health" is one example. ${ }^{101}$ The aim of this study was to gain knowledge about how people communicate whether and how they want to have sex, how they perceive their ability to communicate, and whether that ability has an effect on their well-being. ${ }^{102}$ The new rape law is mentioned as a background to the study, but the study is mainly framed as a matter of sexual and reproductive health. ${ }^{103}$ Another example is Gunnarsson's interview study in the field of gender studies that focuses on how people express sexual consent. It relates to the new rape law and the concept of voluntary participation, but its aim is to investigate the dynamics of consent in human and social processes. ${ }^{104}$ In addition, and also with reference to the new rape law, Holmström et al. conducted an interview study to investigate how young people in Sweden interpret sexual consent and sexual negotiations, and how they understand the legal imperative that sex must be voluntary. ${ }^{105}$ Further examples are educational projects from nongovernmental organizations such as Fatta ${ }^{106}$ and the Swedish Association for Sexuality Education, hereinafter Riksförbundet för Sexuell Upplysning (RFSU) ${ }^{107}$ which offer tools and courses aimed at helping people learn to communicate about sex, express consent, and avoid having sex with someone who does not want to have sex.

Putting the representation of rape in the context of the emergent problem of sexual communication makes visible two discursive effects, which the next section addresses.

\section{F. Towards Choice and Communication in Late Modernity}

First, one effect of the way that the new legislation represents rape as gender-neutral and bound up with choice is that it risks rendering invisible the notion of rape as gendered and unilateral violence. In Sweden, rape was strongly framed as a form of male violence against women and an issue

\footnotetext{
${ }^{96}$ Lena Gunnarsson, "Excuse Me, But Are You Raping Me Now?": Discourse and Experience in (the Grey Areas of) Sexual Violence, 26 Nordic J. FEMINIST \& GENDER Res., 4, 7 (2018).

${ }^{97} I d$. at 6; Lena Karlsson, Towards a Language of Sexual Gray Zones: Feminist Collective Knowledge Building Through Autobiographical Multimedia Storytelling, 19 Feminist Media STUd. 210, 214 (2019).

${ }^{98}$ Karlsson, supra note 97 , at 212 (2019).

${ }^{99} \mathrm{Id}$. at $212-21$.

${ }^{100}$ Gunnarsson, Nordic J. Feminist \& Gender Res., 9 (2018).

${ }^{101}$ Folkhälsomyndigheten, Report 5 June 2019 Sexuell kommunikation, samtycke och hälsa. En enkätstudie om hur personer kommunicerar i sexuella situationer och vilka konsekvenser detta kan få (2019).

${ }^{102} \mathrm{Id}$. at 12 .

${ }^{103} I d$. at 8.

${ }^{104}$ Lena Gunnarsson, SAmtyckesdynamiker: SeX, VÅldTÄKT OCH GrÅZONEn DÄremellan 15-16 (2020).

${ }^{105}$ Charlotta Holmström, Lars Plantin, \& Eva Elmerstig, Complexities of Sexual Consent: Young People's Reasoning in a Swedish Context, 11 Psychol. \& SeXuality 342 (2020).

${ }^{106}$ Fatta! Sex Steg till en Samtyckeskultur, http://samtyckeskultur.nu/\#steg (last visited 28 Aug. 28, 2020).

${ }^{107} \mathrm{Sex}$, Kommunikation och Samspel, https://www.rfsu.se/sex-och-relationer/for-pedagoger-och-yrkesverksamma/metodbanken/ gymnasiet/samtycke-och-omsesidighet/sex-kommunikation-och-samspel/ (last visited Aug. 28, 2020).
} 
of gender inequality in the 1990s. ${ }^{108}$ Although rape is now framed as a gender equality issue in politics at large, ${ }^{109}$ criminal law reforms since the early 2000s have been narrowly concerned with rape from a legal dogmatic perspective and include neither sociological knowledge nor a structural or contextual perspective on sexual violence. ${ }^{110}$ This is true of the most recent reform, and the new legislation intensifies the representation of rape as involving a gender-neutral individual's choice in sexual situations. This portrayal of rape is at odds with feminist understandings that conceptualize sexual violence as part of the continuum of violence against women. ${ }^{11}$ Further, representing rape as something that occurs between equal and non-gendered individuals when they are engaged in the mutual enterprise of having sex is, is turning rape into an agentless mistake rather than an act of unilateral violence. ${ }^{112}$ The critique against the criminal law conceptualization of sexual violence, in short, is that law is particularly poor at comprehending and taking into consideration the structural violence against women of which rape forms a part. ${ }^{113}$ Whereas rape in criminal law discourse is represented as a gender-neutral, individualistic problem, the problem of sexual communication includes considering the way gender norms influence the ability to communicate in sexual situations and stresses the need to problematize normative assumptions about gender to improve sexual communication. A tension exists, however, regarding to what extent sexual violations should be understood as a matter of a structural power hierarchy that subordinates women and privileges male sexuality. ${ }^{114}$ Therefore, the emergent problem of sexual communication can also be seen as a move away from conceptualizing rape as violence against women.

The intersections of gender, sexuality, and power in understanding sexual violence have been thoroughly theorized and my intention here is not to further contribute to this discussion, save to point out that the issue is complex. ${ }^{115}$ In the effort to comprehend the problem of sexual communication and its relation to the representation of rape in criminal law discourse, a way forward might be to consider the role of choice, consent, and communication in late modernity in a wider sense. Illouz argues that in late modernity, choice "is the chief trope under which the self and the will in liberal polities are organized," and to have a self is to exercise choice. ${ }^{116}$ The new rape law and the problem of sexual communication are each part of the organization of intimate relationships in late modern capitalist societies, where choice and consent are the dominant ethical discourse. ${ }^{117}$ The sexual liberation movement and the feminist striving for gender equality both foreground choice and

\footnotetext{
${ }^{108}$ LinNeA Wegerstad, Skyddsvärda Intressen \& StraffVÄrda KRÄNKNingar. OM SeXUAlbrotten I DET StraffrätTSliga Systemet med Utgångspunkt i Brottet Sexuellt Ofredande 162-69 (2015).

${ }^{109}$ Maria Wendt, Våldtäkt som Demokratiproblem: Förändring och Stabilitet i Politik och Debatt, in ANTOLOGI: SJU PeRSPEKTIV PÅ VÅLDTÄKT NCK-RAPPORT 2010:2 137 (2010).

${ }^{110}$ WEGERSTAD, supra note 108 at $184-89,205-09$.

${ }^{111}$ Liz Kelly, Surviving Sexual Violence 76 (1988); Eva Lundgren, Slagen dam. Mäns VÅld MOt Kvinnor I JÄMSTÄLLDA SVERIGE: EN OMFÅNGSUNDERSÖKNING 16-17 (2001).

${ }^{112}$ Coates Linda \& Wade Allan, Telling it like it isn't: Obscuring Perpetrator Responsibility for Violent Crime, 15 DISCOURSE \& Soc'y 499, 501 (2004).

${ }^{113}$ Liz Kelly \& Jill Radford, 'Nothing Really Happened': the Invalidation of Women's Experiences of Sexual Violence, 10 Critical Soc. Pol'y, 39, 51 (1990); Alcoff, Rape AND Resistance, 46-47 (2018).

${ }^{114}$ GunNARSSON, supra note 104, at 348. See generally Karen Boyle, What's in a Name? Theorising the Inter-Relationships of Gender and Violence, 20 FEMINIST TheORY (2019).

${ }^{115}$ See generally Katherine M. Franke, Putting Sex to Work, in Left Legalism/Left Critique (Wendy Brown \& Janet Halley eds., 2002); Catharine A. MacKinnon, Women's lives, Men's laws (2005); Ann J. Cahill, Rethinking Rape (2001); Stevi Jackson, The Social Context of Rape: Sexual Scripts and Motivation, 1 WomEN's STUD. INT'L Q, 27 (1978). SMART, supra note 27; Vikki Bell, Beyond the 'Thorny Question'. Feminism, Focault and the Desexualisation of Rape, 19 INT'L J. Soc'y L., 83 (1991).

${ }^{116}$ Eva Illouz, The End of Love: A Sociology of Negative Relations 15-16 (2019); Others have situated rape in the context of neo-liberalism. See generally Lise Gotell, Canadian Sexual Assault Law: Neoliberalism and the Erosion of FeministInspired Law Reforms, in Rethinking Rape Law : International and Comparative Perspectives (Vanessa Munro \& Clare McGlynn eds., 2010); Vanessa E. Munro, Shifting Sands? Consent, Context and Vulnerability in Contemporary Sexual Offences Policy in England and Wales, 26 Soc. \& L. STUD. 417(2017).

${ }^{117}$ ILLOUZ, supra note 116 at $15-19$.
} 
consent. ${ }^{118}$ Against this background, the shift to consent-based rape laws in Sweden and elsewhere is simultaneously a feminist triumph and an extension of late capitalism consumer rationality. In addition, the focus on communication can be understood against the background of emotional capitalism, where the ability to communicate in sexual situations can be understood as a form of an emotional capital that has emerged as a new form of capital in late modernity. ${ }^{119}$

Second, while the legislative materials analyzed in Section D aim at constructing clear and unambiguous legal concepts-i.e. nonvoluntary participation-the problem of sexual communication aims rather at embracing complexity and brings to the fore nuances and ambivalence in sexual encounters. The aim of the \#talkaboutit campaign was to problematize the black-and-white distinction between rape and sex and to make the gray zones visible. The study by the Public Health Agency emphasizes that sexual consent can be complex and context-dependent, and suggests doing further research into these complexities and the norms surrounding sexual communication. ${ }^{120}$ Gunnarsson's study underscores that the process of consent is-the same time-very simple and very complex, and suggests further collective reflections on ambiguousness in sexual relations. ${ }^{121}$ A similar conclusion was reached by Holmström et al. ${ }^{122}$ Obviously, there is a contradiction here. If sexual communication is complex and if it is difficult to pin down the exact difference between rape and sex, it seems futile to try to achieve a proper definition of rape in criminal law.

This contradiction can be further explored by considering sex offense laws and morality in the longer perspective. The modern history of sexual offenses-the ninetenth to twenty-first centuries - in Swedish criminal law is usually presented as a narrative where the primary good has changed from public morality to individual integrity. ${ }^{123}$ The law on sexual offenses has gradually improved since the Penal Code of 1864 in such a way that the legal protection of sexual integrity has become increasingly comprehensive-for example, the definition of rape has expanded considerably — while crimes against decency_-for example, fornication against nature — have been abolished. In a previous work I have shown that along with this development, sexuality also became something positive and worthy of protection, and a part of the subject's inner personality. ${ }^{124}$ This means that sexual criminal offenses had to be understood in relation to this lustful, mutual, erotic sexuality. The way rape is represented as a matter of sex in the most recent rape law reform is therefore not something entirely new or different; instead, it is the result of a lengthy process in the modern history of sexual offenses. What is different from before is that the reformed rape legislation now explicitly frames rape as a matter of sex, choice, and communication.

The narrative in which morality has been replaced by the individual's sexual integrity and sexual self-determination corresponds with a larger shift from a thick normativity to a thin, procedural normativity that governs intimate relations in late modernity. ${ }^{125}$ Thick normativity, says Illouz,

"contains elaborate stories and prescriptions that define actions in terms of good and bad, immoral and moral, pure and impure, shameful and commendable, virtuous and vile, and thus connects human behavior to cultural cosmologies, large collective stories ... that contain definite conceptions of the good and the bad, the moral and the immoral."126

\footnotetext{
${ }^{118} I d$. at $54-59$.

${ }^{119}$ Eva Illouz, Cold Intimacies: The Making of Emotional Capitalism 5, 62-67 (2007).

${ }^{120}$ Folkhälsomyndigheten, supra note 101, at 38-40 (2019).

${ }^{121}$ Gunnarsson, supra note 114 at $88-91,335-41$.

${ }^{122}$ Holmström, supra note 105 , at 13.

${ }^{123}$ WEGERSTAD, supra note 108 , at 73-75.

${ }^{124} \mathrm{Id}$. at $317-22$.

${ }^{125}$ ILlOUZ, supra note 116 , at 58

${ }^{126} I d$.
} 
Thin normativity, on the other hand, "gives individuals the right to decide about the moral content of their preferences and focuses on the rules and procedures to secure respect for the psychic and bodily autonomy of the individual." 127 Thin normativity is silent "on the moral valence of actions, and evaluates them in reference to the degree to which they respect the subject's autonomy and capacity to experience pleasure." 128 This thin normativity, I suggest, is apparent both in criminal law discourse and in how the problem of sexual communication is portrayed. But it is rather inadequate for deciding when to attribute blameworthiness. As many have shown, consent-or procedural normativity-is a poor concept when it comes to defining blameworthy behavior, or understanding sexual violence, both in the legal context and elsewhere. ${ }^{129}$ I suggest that the role of criminal law in providing guidelines for sexual behavior needs to be explored further. Criminal legal regulation of rape is used to put forward the normative stance that sex should be voluntary. The increasing engagement of criminal law as a response to sexual violence that we have witnessed in many jurisdictions can, against the background of the current state of thin normativity, be a sign of a certain expectation of criminal law to, in Illouz's words quoted above, define actions in terms of good and bad, immoral and moral.

\section{G. Connecting Legal Uncertainty with Sexual Communication}

The effects I have described above engender more questions than answers and concern theoretical and practical challenges regarding the interplay between criminalization, feminist activism and gender politics, and the role of rape laws in sexual educational projects. Rape laws that center the choice and consent of the subject of criminal protection-whether in terms of a "no means no" model or an "only yes means yes" model-are here to stay, in Sweden and elsewhere. The exercise of choice is too central to the very understanding of the self in late modernity to be left out of rape crime policy. In addition, the emergent problem of sexual communication is a discursive framing of rape that is related to how individuals perceive and express communication and violations in sexual encounters. Sexual communication, too, is central for the very understanding of the self in late modernity.

At the same time, the legal uncertainty pointed out in Section C must not be overlooked. It is problematic because it goes against the fundamental rule of law principle that criminal provisions must be predictable. In addition, it matters for crime prevention. As Larcombe puts it, "[i]f the criminal law cannot communicate and maintain clear and accepted norms, it has no chance of guiding conduct and influencing community attitudes and values so as to prevent sexual violence." 130 Acknowledging these problems, I insist that the uncertainty that accompanies the new rape law is not in itself an argument against a rape definition based on non-voluntariness. Neither is the solution a more refined statutory wording. ${ }^{131}$ The great scope for discretion that the new rape law has created requires, in a more explicit way than before, that criminal justice practitioners have some kind of common conception of how people behave in sexual situations and a normative comprehension of what constitutes blameworthy-and acceptable-behavior in sexual

\footnotetext{
${ }^{127} I d$.

${ }^{128} I$.

${ }^{129}$ Munro, supra note 5, at 926-35; MacKinnon, supra note 7 at 439-450; Eithne Dowds, Towards a Contextual Definition of Rape: Consent, Coercion and Constructive Force, 83 Modern L. Rev.35, 42-52 (2020) Monika Grønli Rosten, Cultivating Ethical Negotiations or Fetishising Consent in BDSM, in RAPE IN THE NORDIC COUNTRIES. COMMUNITY AND CHANGE 45-46 (Marie Bruvik Heinskou, et al. eds., 2019).

${ }^{130}$ Wendy Larcombe, Limits of the Criminal Law for Preventing Sexual Violence, in Preventing SEXUAL ViOlence: Interdisciplinary Approaches to Overcoming a Rape Culture 79, (Nicola Henry \& Anastasia Powell eds., 2014).

${ }^{131}$ While recent theoretically and philosophically informed discussions on rape are highly important, to secure legitimate decision-making, legal professionals may benefit more from empirically grounded research. For examples of the former, see generally John Gardner, The Opposite of Rape, 38 OxFord J. LEGAL STUD. (2018); Karamvir Chadha, Sexual Consent and Having Sex Together, 40 OxFord J. LEGAL STUD (2018).
} 
encounters. The courts must provide meaning to concepts such as choice, consent, and communication to accurately attribute responsibility for rape in individual cases. To punish individuals for transgressing criminal legal norms may be viewed as illegitimate if the rape law departs from accepted social norms. ${ }^{132}$ The emergent problem of sexual communication may be conceived as a search for substantial knowledge on how people behave in sexual situations and what the accepted social norms are, and, if considered, may therefore provide normative thickness to criminal law.

I suggest that research, policy, and legal decision making should take into account the interrelation between criminal legal regulation of rape and knowledge about sexual communication. Consider the following examples. When asked "[h]ow did you show that you wanted to have sex with the person you last had sex with?", the majority answered that they did so verbally and/or with body language and eye contact. ${ }^{133}$ However, eleven percent of the respondents answered that they did not know whether or how they showed this and three percent answered "did not show." ${ }^{34}$ While a majority of the respondents stated that they have the ability to communicate to a partner whether, when, and how they want to have sex-fifty-six percent-ten percent answered that their communication skills do not work. ${ }^{135}$ How does criminal law deal with an inability to communicate? Conversely, can the new rape law enhance individuals' ability to communicate in sexual situations? Further, Gunnarsson's study suggest that whether a person perceives a sexual transgression as a violation depends to some extent upon how the person responsible for the transgression deals with the mistake in terms of correction and repair. ${ }^{136}$ To what extent does criminal law accommodate mistakes in sexual situations that have been corrected? Does the new rape law facilitate for individuals to correct and repair transgressions in sexual situations? Further, if communication in sexual situations is a skill that we need to learn, as Fatta and RFSU suggest, does criminal law consider the extent to which young people, especially, have been given the opportunity to learn to communicate and tune in to other people? There are no easy answers to these questions, but I contend that a rape law that addresses rape as a matter of choice and communication in sexual situations and sends the normative message that sex must be voluntary needs to consider this kind of knowledge to attribute blameworthiness with certainty and legitimacy.

\section{H. To Conclude}

In criminal law discourse, rape is represented as a problem that has to do with sex, choice, and communication. This characterization of rape relates to the emergent problem of sexual communication within disparate spheres such as governmental public health, social media campaigns, sexual education, and gender studies research. Both can also be related to a discursive reframing of rape that has taken place in Sweden in recent decades-a move from addressing rape as gendered violence towards framing rape as a question of individual sexual integrity and self-determination. I have further suggested that the centrality of choice and communication is part of a move from thick normativity to a thin one, and that choice and communication are crucial for the very construction of the self in late modernity. It is difficult not to concur with the message sent by the Swedish government when the new rape law was introduced that "sex must be voluntary." However, the new rape definition comes with uncertainties that need to be addressed further, both to overcome the pedagogical challenge of explaining in more detail what behavior amounts to a crime and to accurately attribute criminal blameworthiness in individual cases.

\footnotetext{
${ }^{132}$ Larcombe, supra note 130 , at 79.

${ }^{133}$ Folkhälsomyndigheten, supra note 101 , at 17.

${ }^{134} I d$.

${ }^{135} \mathrm{Id}$. at $23-24$.

${ }^{136}$ GunNARSSON, supra note 104 , at 91 .
} 
The current uncertainty is not only a problem for future defendants, but also for victims of sexual violence and for crime prevention at large. As policy has moved towards governing the gray zones of sex with criminal law, crime policy may benefit from studies about sexual communication to accurately attribute criminal responsibility. As mentioned in the introduction, there are several jurisdictions where rape reform is set to happen soon. A lesson from Sweden is that future legal reforms should put less effort into describing what the subject of criminal protection should do to avoid having nonvoluntary sex, and pay more attention to defining the kind of behavior by the subject of criminal responsibility that is worthy of criminal censure and punishment. To do so, the legislative process may benefit from knowledge of how people communicate in sexual situations and must not address the problem of rape as solely a legal positivistic quest for the most accurate legal wording.

Cite this article: Wegerstad L (2021). Sex Must Be Voluntary: Sexual Communication and the New Definition of Rape in Sweden. German Law Journal 22, 734-752. https://doi.org/10.1017/glj.2021.32 